\title{
The prevalence of Mycoplasma pneumoniae infection in patients with ventilator-associated pneumonia hospitalized in intensive care unit
}

\author{
Shirin Mafi ${ }^{1}$, Fatemeh Sakhaee ${ }^{2}$, Mohsen Zargar ${ }^{3}$, Farzam Vaziri', Masoud Zarei ${ }^{4}$, Fatemeh Rahimi Jamnani ${ }^{2}$, \\ Seyed Davar Siadat ${ }^{2}$, Abolfazl Fateh ${ }^{2}$ \\ ${ }^{I}$ Department of Biology, Science and Research Branch, Islamic Azad University, Tehran, Iran \\ ${ }^{2}$ Department of Mycobacteriology and Pulmonary Research, Microbiology Research Center (MRC), Pasteur Institute of \\ Iran, Tehran, Iran \\ ${ }^{3}$ Faculty of Science, Qom Branch, Islamic Azad University, Qom, Iran \\ ${ }^{4}$ Molecular Laboratory of Erfan Niyayesh Hospital, Tehran, Iran
}

\begin{abstract}
Background: Ventilator-associated pneumonia (VAP) is a type of hospital acquired pneumonia with the mortality rate between $27 \%$ and $76 \%$ that develops more than $48-72 \mathrm{~h}$ after endotracheal intubation. Possible causes leading to this infection can be Mycoplasma pneumoniae. The objective of this study was to determine the presence of Mycoplasma pneumoniae in bronchoalveolar samples of patients with VAP who admitted in the intensive care unit (ICU).

Materials and methods: In this cross-sectional study, 103 bronchoalveolar lavage samples were collected from VAP patients who admitted to ICU in Loghman, Erfan Niyayesh and Erfan Hospitals. Then, samples were investigated for presence of Mycoplasma pneumoniae using nested-PCR method with 16S rRNA gene.

Results: 4 (3.9\%) patients were positive for Mycoplasma pneumoniae. There was a significant relationship between the positive infectious agents with clinical signs $(\mathrm{P}=0.017)$ and the duration of using ventilator $(\mathrm{P}=0.043)$.

Conclusion: The results of this study, as a first study in Iran, showed that Mycoplasma pneumoniae can be considered as true pathogens of the respiratory tract in patients with VAP and should be given more attention. To confirm the results of this study, further research is needed to reveal the association of this bacterium with VAP.
\end{abstract}

Keywords: Ventilator-associated pneumonia, Mycoplasma pneumoniae, $16 S$ rRNA gene.

Cited as: Mafi SH, Sakhaee F, Zargar M, Vaziri F, Zarei M, Rahimi Jamnani F, et al. The prevalence of Mycoplasma pneumoniae infection in patients with ventilator-associated pneumonia hospitalized in intensive care unit. Medical Science Journal of Islamic Azad University, Tehran Medical Branch 2019; 29(4): 313-321.

Correspondence to: Abolfazl Fateh

Tel: +982164112823

E-mail: afateh2@gmail.com

ORCID ID: 0000-0002-2043-8523

Received: 20 May 2018; Accepted: 3 Sep 2018 
مجله علوم يزشكى دانشگاه آزاد اسلامى

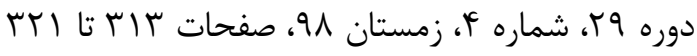

Original

Article

\section{شيوع عفونت مايكو يلاسما ينومونيه در بيماران مبتلا به ينومونى مرتبط با ونتيلاتور بسترى در بخش مراقبتهاى ويثه}

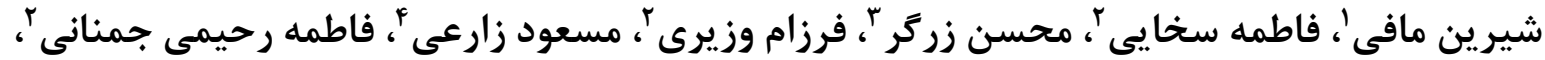

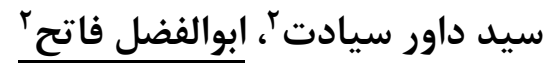

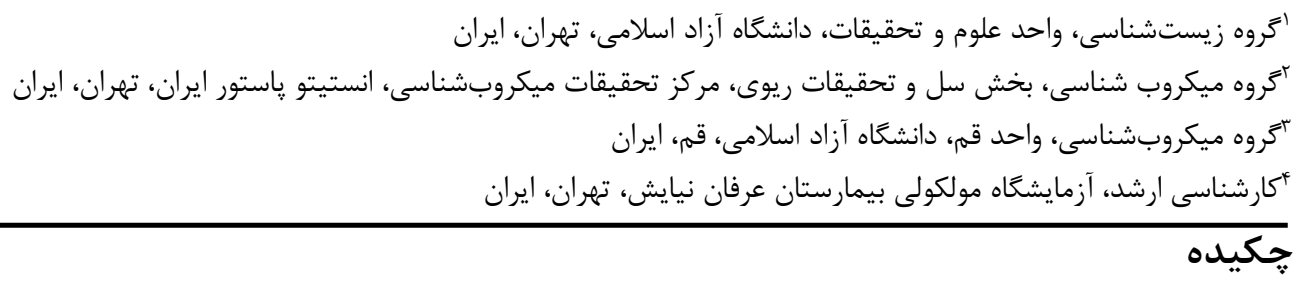

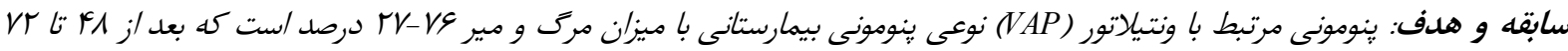

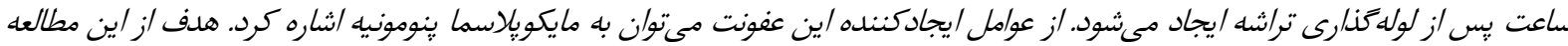

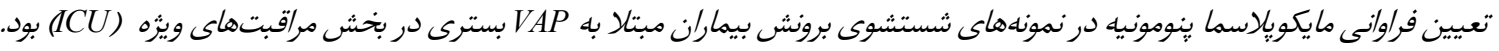

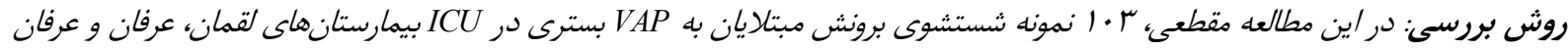

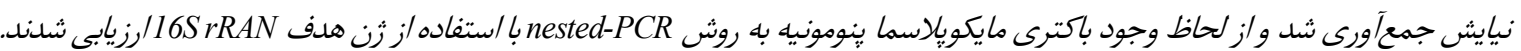

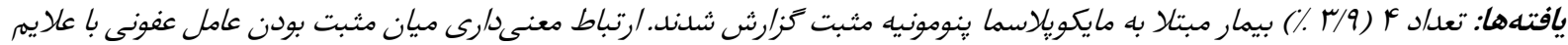

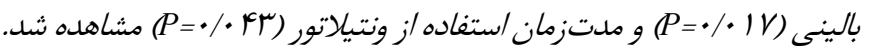

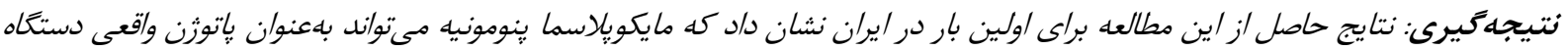

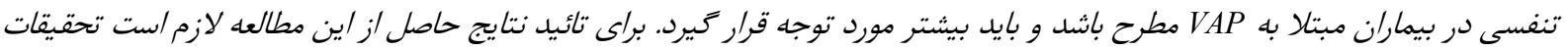

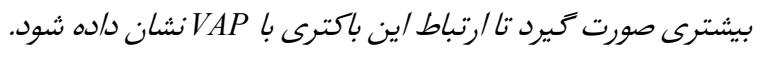

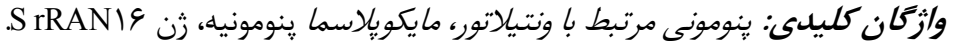

بسترى در ICU است كه VVI\% از بيمـاران را تحـت تـأثير قـرار مقله

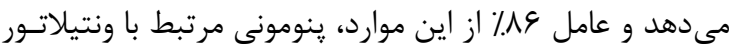

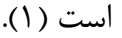
بر طبق دستورالعمل انجمن بيمارىهاى عفونى و بيمارىهـاى (1)

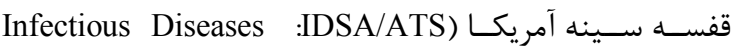
،Society of America /American Thoracic Society

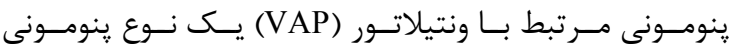

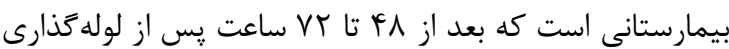

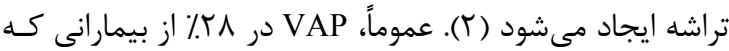

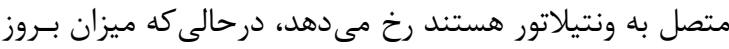
بيماران بسترى در بخش مراقبتهاى ويـرزه (ICU) نـهـ تنهـا از

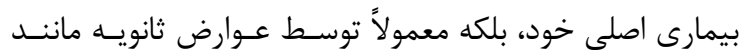

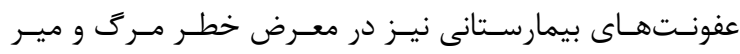
هستند. ينومـونى بيمارسـتانى يـك عفونـت رايـج در بيمـاران

\footnotetext{
آدرس نويسنده مسئول: انستيتوياستورايران، بخـش سل و تحقيقـات ريـوى، كُروه ميكروب شناسى.

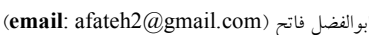
ORCID ID: 0000-0002-2043-8523 تاريخ دريافت مقاله: TV/T/T/TQ

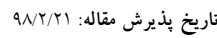


عفونى تنفسى مانــد كلاميـديا ينومونيـه نـدارد، تشـخيص بهموقع اين گروه از عفونتها ضرورى به نظر مىرسد (1).

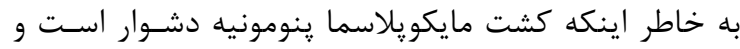

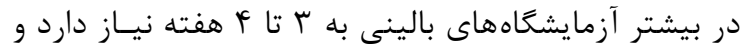
با توجه به محدوديتهاى سرولوزى به دليـل وجـود نتـايج مثبت كاذب (Y) (I)، درنتيجه تشخيص مستقيم و سريع ايسن

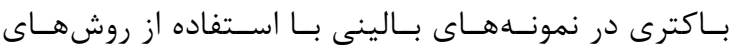
مولكولى انجام مىشود. در حال حاضر روشهاى مبتنى بـر

PCR

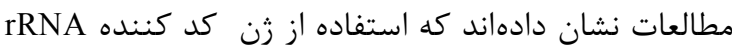
بـراى شناسـايى ايسن بـاكترى مناسـب بـه نظــر مى رسند. به همــين منظـور، بـراى تشـخيص مايكوريلاسـما

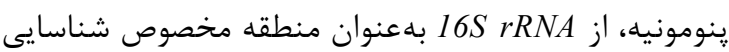

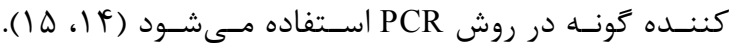
مزيت استفاده از توالىهاى $16 S$ rRNA سطح بالاى منــاطق حفاظتشده و همجنين وجود مناطق بسيار متغير متعلق به

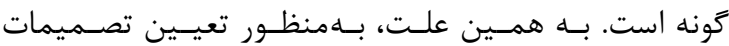

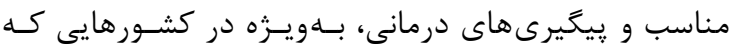

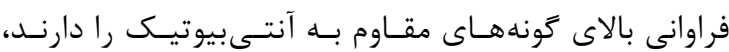
شناسـايى نشـانگرهاى مناسـب بــراى تمــايز بــين عوامــل ايجادكننده ينومونى باكتريايى و ويروسسى از ارزش زيـادى

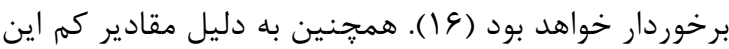
عوامل عفونى، استفاده از روش هاى مولكـولى بــا حساسـيت

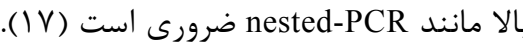

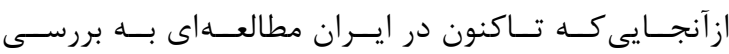
مايكويلاسما ينومونيه در بيماران VAP نيرداخته است و بـا توجه به اهميت باكترى هاى ايجادكننده ينومونى غير شايع

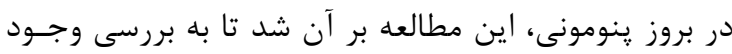

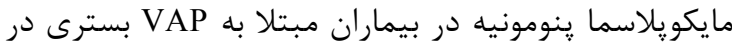

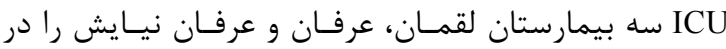
تهران بتردازد.

\section{مواد و روشها جمع آورى نمونه}

مطالعه حاضر يكى مطالعه مقطعى اسـت كـهـ در آن تعـداد

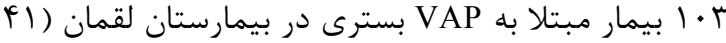

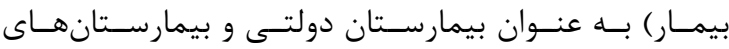

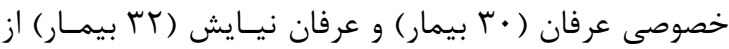
شهريورماه سالهو تا آذرماه צوسا بر اساس معيارهاى ورود
آن با مدتزمان استفاده با ونتيلاتور متغير است. ميزان بروز VAP براى ه روز اول ب/، براى روزهاى ع تا • ا به ميـزان

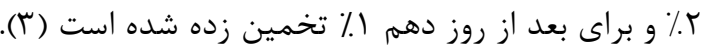
ميزان مرگ و مير VAP بين VV تا V V درصد است. ميـزان مرگ و مير در بيماران مبتلا به VAP بيشتر در عفونست بـا سودموناسها و همجنين اسنتيتوباكتر بومانى ديده مى شود

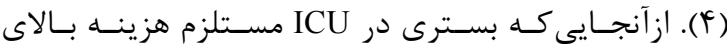
بيمارسـتانى اسـت و بــه دليـل اينكـــ VAP باعـث اقامست

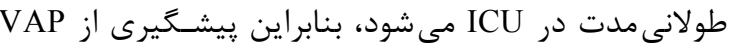

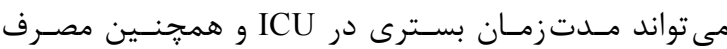
منابع و هزينهای بعاى بعدى را كاهش دهد (ه).

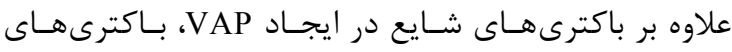

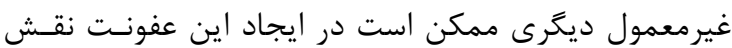

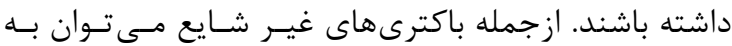
مايكويلاسما ينومونيه، لزيونلا ينوموفيلا و كلاميديا ينومونيه اشاره داشت (9) (9) مايكو يلاسماها كوجگ ترين باكترى هاى عفونى شناخته شده

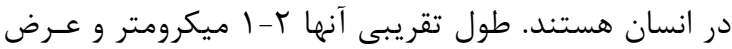

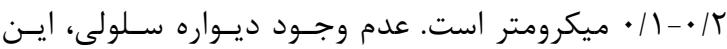
ار كانيسمها را جندشكلى نشان مىدهد و باعث مقاوم شدن اين باكترى ها در برابر آنتـى بيوتيـكـهـاى مـؤثر بـر ديـواره

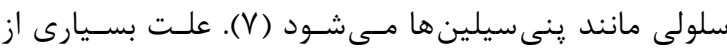

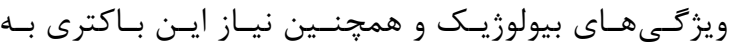
مكمل هاى محيطى ثيجيده كه براى كشت اين اركانيسهم در

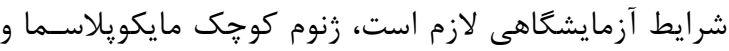
قابليتهاى بيوسنتزى محدود آن است (^).

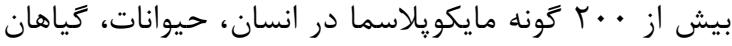
و بنديايان شناسايى شده است، اما تنهها تعداد كمـى از آنهـا براى انسان بيمارىزا هستند كه از شناخته شدهترين آنهـا مى توان به مايكوريلاسـما ينومونيـهـ اشـاره داشـت (9). ايسن

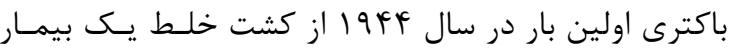
مبتلا به ينومونى جدا شد و در ابتدا عامـل ايتـون (Eaton) ناميده شد و در سال ·99 19 مشـخص شـد كـهـ عامـل ايسن ينومونى مايكويلاسما ينومونيه است ( • (). ينومونى ناشى از

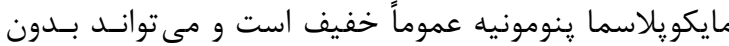
علامت باشد و يا اينكه فـرد مبـتلا داراى ينومسونى شـديد، كمخونى، گرفتار شدن سيستم عصبى و يا ضايعات يوسـتى باشد (^).

از آنجايى كـه علايـهم بـالينى بيمـاران مبـتلا مايكوريلاسـما ينومونيه تفاوت جندانى با بيماران مبـتلا بـهـ سـاير عوامـل 
مواد مصرفى استفادهشده در مرحله اول صـورت گرفـت، بـاـ

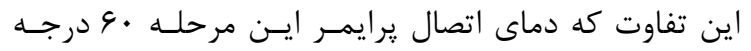

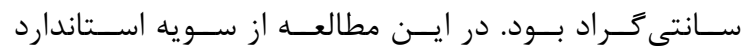

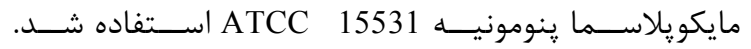

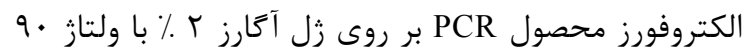

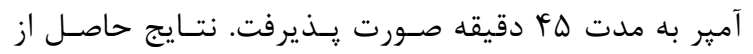
الكتروفورز با استفاده از نور ماورا بنفش مورد ارزيابى قـرار

\section{تحليل دادهها}

تحليل آمارى توسط نرمافزار آمارى SPSS ورثن rك انجـام شد. از آزمون كولمو گروف اسـميرنوف بـراى تعيـين نرمـال بودن توزيع داده هـاى كمـى اسـتفاده شـد. جهــت تحليـل متغيرهاى ييوسته و متغيرهاى طبقه بندى شده و كيفى، به به اسه

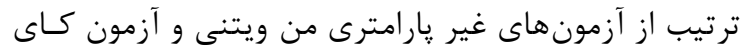

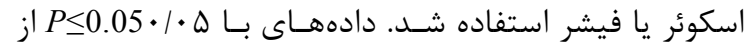
نظر آمارى معنى دار در نظر گرفته شدند.

\section{بافتهها}

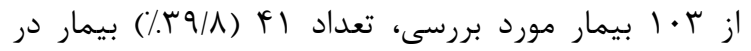

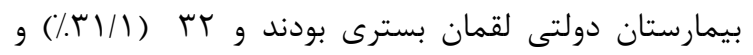

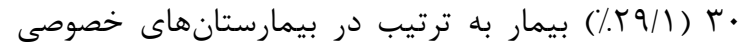

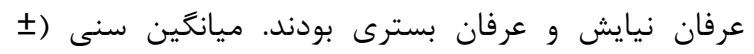
انحراف معيار) بيماران بسترى در بيمارستان لقمان، عرفان نيايش و عرفان به ترتيب برابر با 19/r \

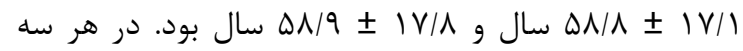
بيمارستان بيشتر بيماران مرد بودند و بيشترين بيماران

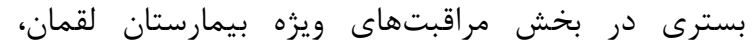

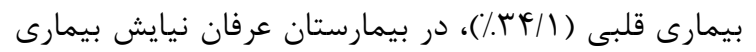

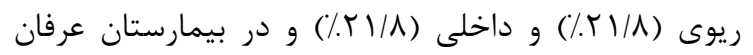
عامل بسترى بيمارى مغزى (Y/V/V/\%) بود. اكثريت بيماران

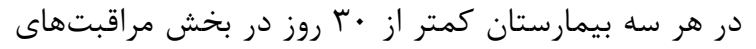

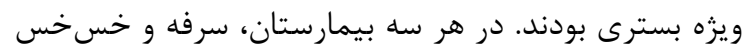

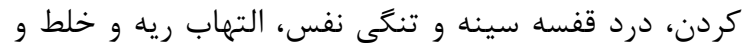
تب و لرز و التهاب كلو عمده علايم بالينى در بيماران بودند

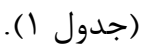

(بيماران بسترى در بخش ICU كه متصل به دستخاه تهويه

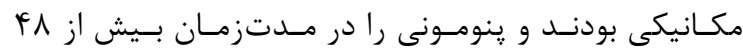
ساعت نشان داده بودند) و معيارهاى خروج (شامل بيمـاران مبتلا به ينومونى قبل از اتصال به دستخاه تهويه مكانيكى و

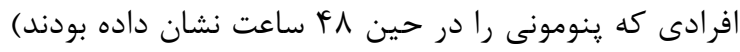

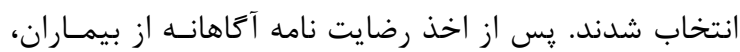
نمونه هاى شستشوى برونش بيماران گرفتــه شـد و يـس از

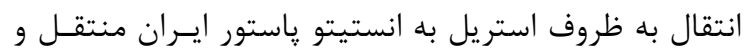

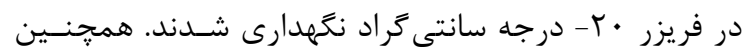
مطالعه فوق در كميتــه اخــلاق انسـتيتو ياسـتور بــا شـماره

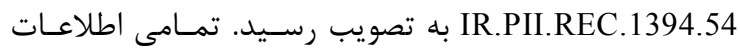
دموكرافيك از قبيل سن، جنس و علائسم بـالينى از زيرونـده بيماران استخراج شدند.

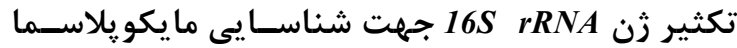
ينومونيه

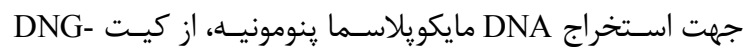

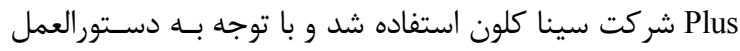
كيت، DNA اسـتخراج كرديـد. جهـت شنـاسـايى مايكو يلاسـما ينومونيه از روش nested-PCR بر طبق مطالعه Han و همكـاران

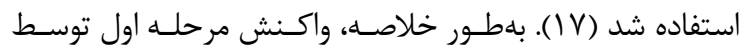

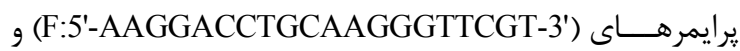
(R:5'-CTCTAGCCATTACCTGCTAA-3') دماى واسرشت اوليه F F درجه سانتى گراد به مدت ينج دقيقـه و

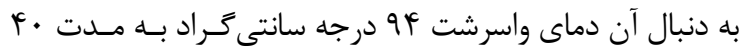

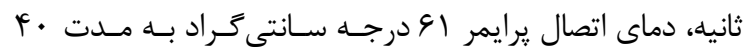

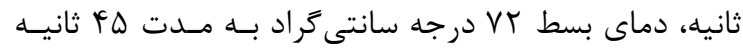

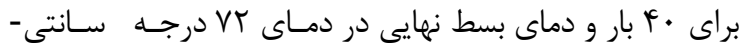

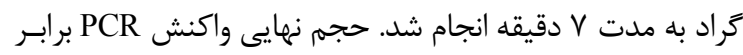

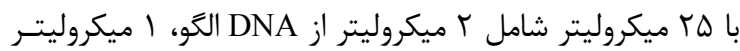

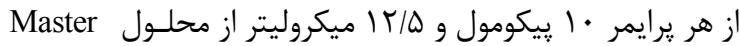

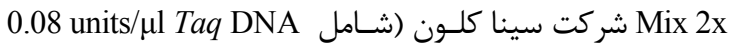
polymerase, $3 \mathrm{mM} \mathrm{MgCl} 2,0.4 \mathrm{mM}$ dATP, $0.4 \mathrm{mM}$ (dCTP, 0.4 mM dGTP and 0.4 mM dTTP. جهت به حجم رساندن، از آب دو بار تقطير استريل استفاده شد.

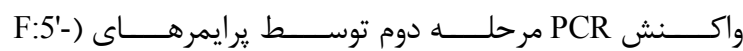
R:5'-) و (CTCTAGCCATTACCTGCTAA-3' (ACTCCTACGGGAGGCAGCAGTA-3' 


\begin{tabular}{|c|c|c|c|c|}
\hline \multirow[b]{2}{*}{$P$-value } & \multicolumn{2}{|c|}{ 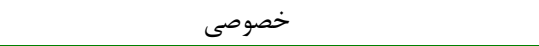 } & \multicolumn{2}{|l|}{ 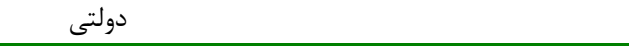 } \\
\hline & $\begin{array}{c}\text { بيمارستان عرفان } \\
\text { (n = ( ) }\end{array}$ & 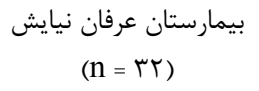 & $\begin{array}{c}\text { بيمارستان لقمان } \\
(n=f \mid(1)\end{array}$ & 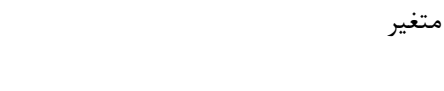 \\
\hline \multirow[t]{3}{*}{.$/ 199$} & & & & 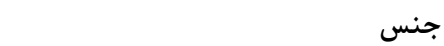 \\
\hline & $(/ .94 / V) \mathrm{r}$ & $(/ . \Delta r / I) I V$ & $(/ V r / r) r \cdot$ & 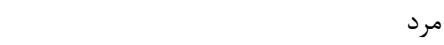 \\
\hline & ( & $(/ . \uparrow 9 / 9) \backslash \Delta$ & $(/ . T \& / \Lambda) 11$ & 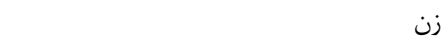 \\
\hline$\cdot|r 4|$ & $\Delta \Lambda / 9 \pm I V / \Lambda$ & $\Delta \Lambda / \Lambda \pm I V / I$ & $9 \% / 9 \pm 19 / 4$ & ميانگين سنى \\
\hline \multirow[t]{6}{*}{$\cdot / 49 V$} & & & & علت بسترى در بخش ICU \\
\hline & $(/ .1 T / r) F$ & $(/, T / / \Lambda) \vee$ & $(/ .1 \mathrm{~V} / 1) \mathrm{V}$ & 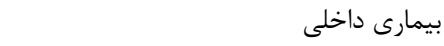 \\
\hline & $(/ / Y \& / V) \wedge$ & $(/ . \wedge / \Lambda)^{9}$ & $(/ . M T)^{9}$ & 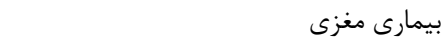 \\
\hline & $(/ .19 / V) \Delta$ & $(/ .1 \wedge / \Lambda) \varphi$ & $(/ . r F / I) \mid \mathcal{F}$ & بيمارى قلبى \\
\hline & $(/ T / T) V$ & $(/, T / /) V$ & $(/ . V / \mu) r$ & بيمارى ريوى \\
\hline & $(/ / T \cdot)^{9}$ & $(/ . \wedge / \Lambda)^{4}$ & $(/ .19 / 0) \wedge$ & جراحى \\
\hline \multirow[t]{3}{*}{.$/ 1 \vee 9$} & & & & مدت زمان بسترى در ICU \\
\hline & $(\% \cdot V \cdot) T_{1}$ & $(/ . G T / \Delta) T \cdot$ & $(/ . \Delta I / T) Y I$ & كمتر از • · روز \\
\hline & $(/ . r \cdot)^{9} 9$ & $(/ . r V / \Delta) \mid r$ & $(/ / \uparrow \wedge / \Lambda) r \cdot$ & بيشتر از • إ روز \\
\hline \multirow[t]{3}{*}{$\cdot / 194$} & & & & مدت زمان استفاده از دستخاه ونتيلاتور \\
\hline & $(/ . \Lambda 9 / V)$ YG & $(/ .9 \mu / \Lambda) r \cdot$ & $(/ . V \wedge) T^{2}$ & كمتر از • • آروز \\
\hline & $(/ . I r / r) F$ & $(/ .9 / \Gamma) r$ & $(/ . r T) 9$ & بيشتر از • · روز \\
\hline \multirow[t]{5}{*}{$\cdot \mid 901$} & & & & علائم بالينى \\
\hline & $(/ .9 / / r) Y \Lambda$ & $(/ .9 \mu / \Lambda) r$. & $(/ .9 \vee / 9) \mathcal{F}$. & سرفه و خس خس كردن \\
\hline & $(/ . \Lambda \mu / \mu) r \Delta$ & $(/ .9 \cdot 19) r q$ & $(/ .9 r / V) r \wedge$ & درد قفسه سينه و تنكَى نفس \\
\hline & (/VG/V) r r & $(/ . \Lambda F / F) T V$ & $(/ . q \cdot / r) r V$ & التهاب ريه و خلط \\
\hline & $(/ V \cdot) T_{1}$ & $(/ .9 N / \Lambda) \mathrm{rT}$ & $(/ . \Lambda Y / q) r Y$ & تب و لرز و همويتزى \\
\hline \multirow[t]{3}{*}{$\cdot / 1 \Delta T$} & & & & عفونت مايكويلاسما ينومونيه \\
\hline & $(/ . \Gamma / \Gamma) 1$ & $(/ / \Gamma / 1) 1$ & $(/ . r / 9) r$ & مثبت \\
\hline & $(/ . ৭ 9 / V)$ ५ & (/.q9/9) (1 & $(/ . q \Delta / 1) r q$ & منفى \\
\hline
\end{tabular}

ميانكين سنى بيماران (土 انحراف معيار) در بيماران مبتلا

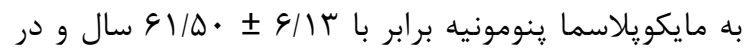

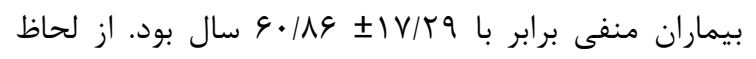

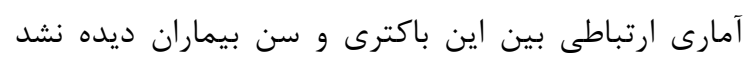

$$
\text { (p=•/19r) }
$$

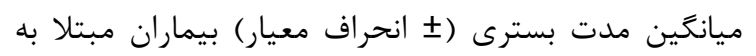

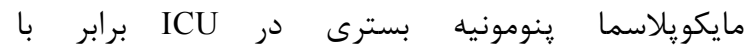
19

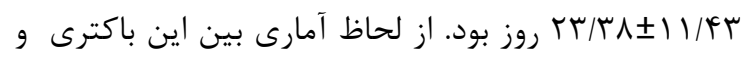

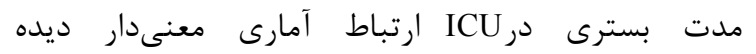

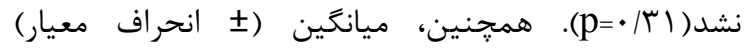

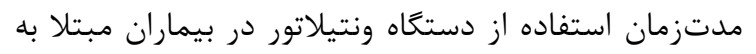

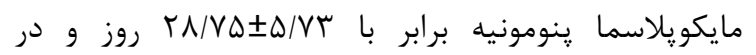

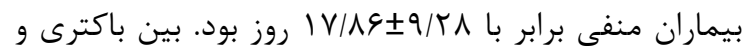

جهت تائيد وجود مايكويلاسما ينومونيه در نمونهاى بالينى از روش nested-PCR استفاده شد. طول محصول

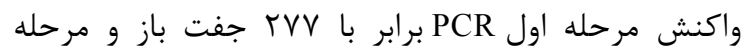

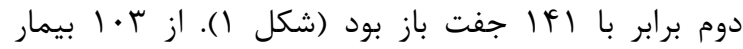

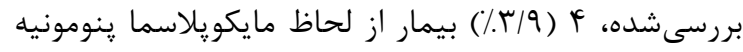

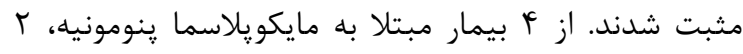

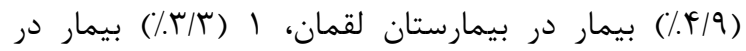

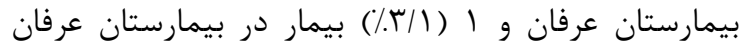

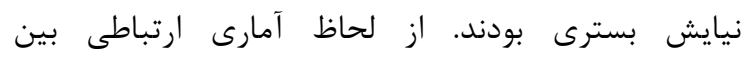

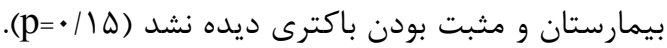

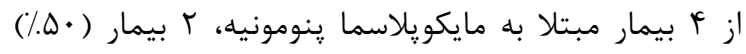

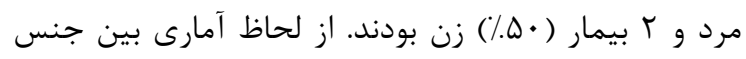

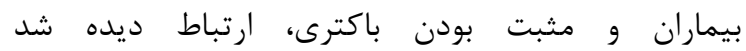
.$(p=\cdot / \cdot r \Delta)$ 


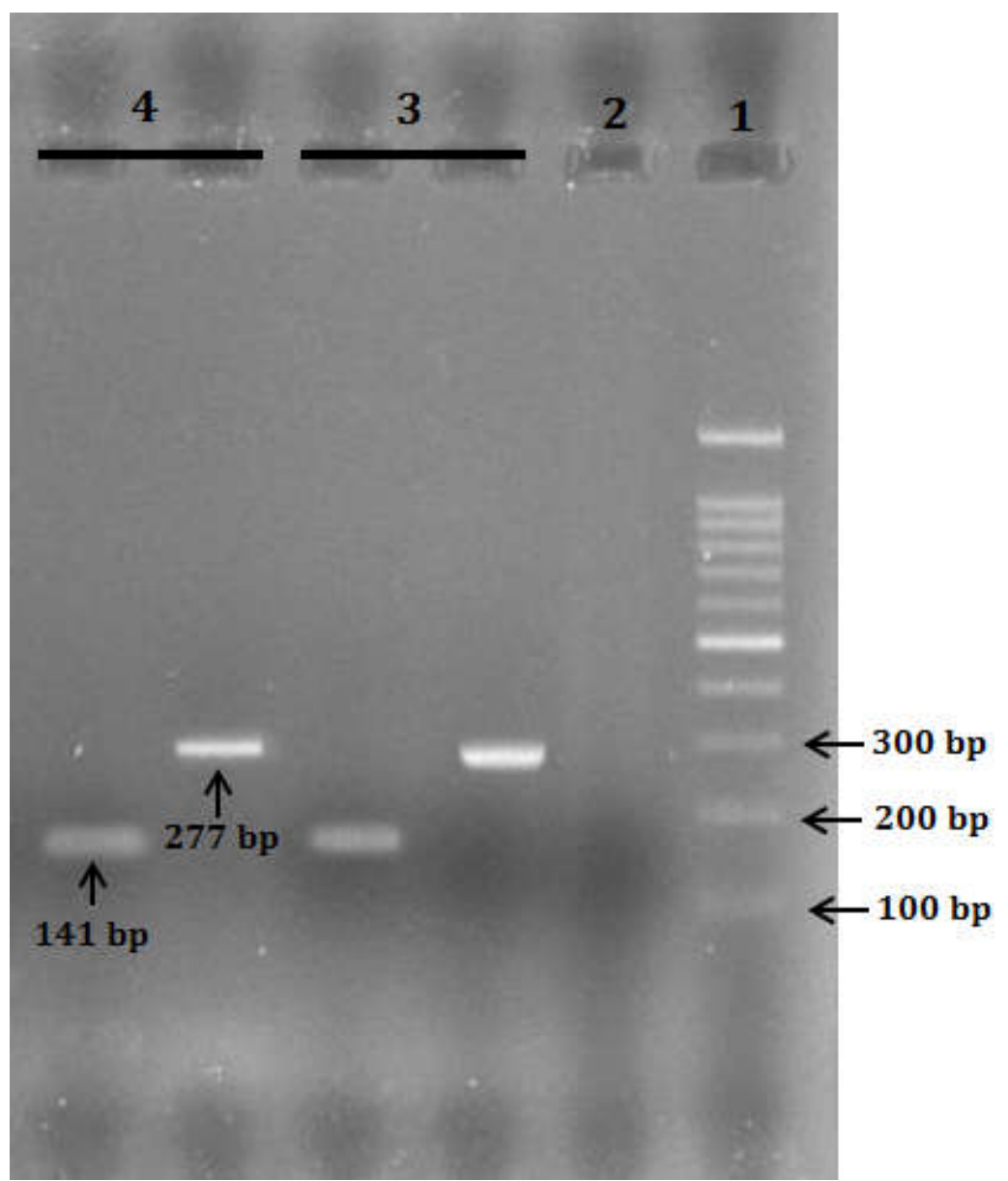

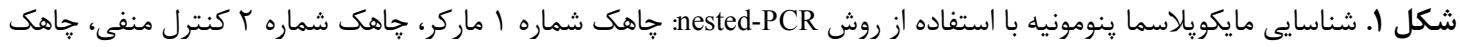

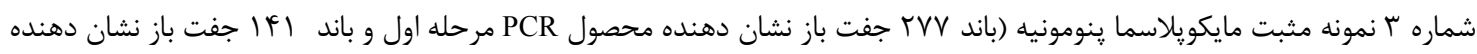

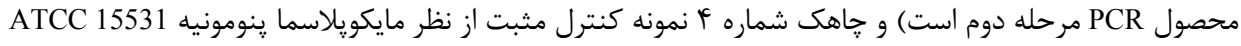

\section{بحث}

بعد از عفونت ادرارى، يُنومونى بيمارستانى دومين عفونت

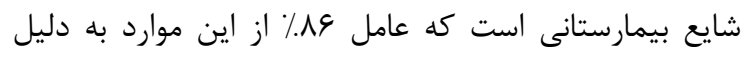

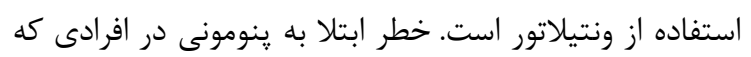

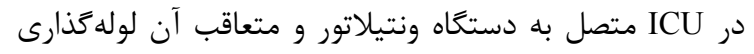

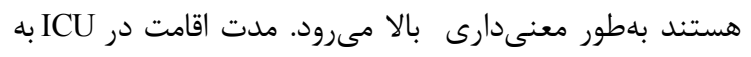

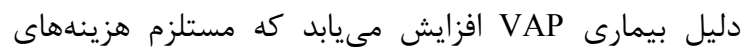

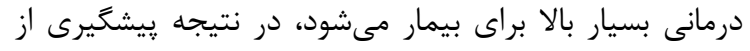

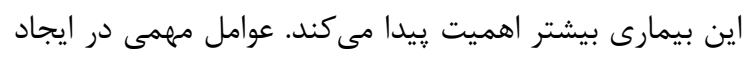

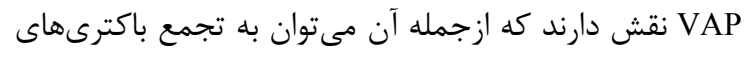

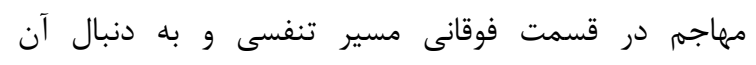

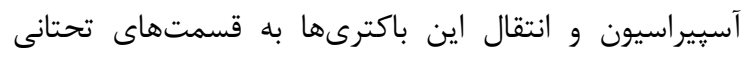

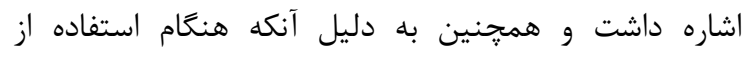

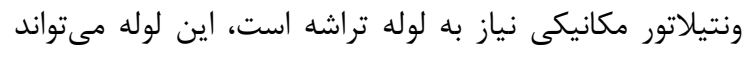

مدتزمان استفاده از دستخاه ونتيلاتور ارتباط آمارى ديده شد (p)

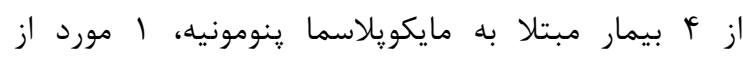

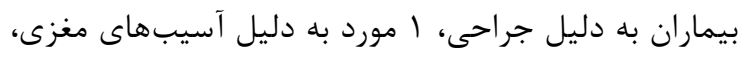

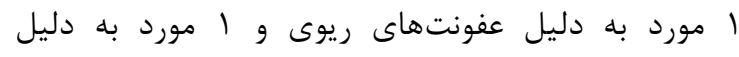

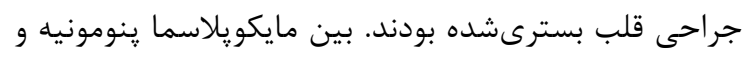

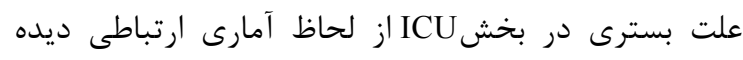

$$
\text { نشد (p=) (p) }
$$

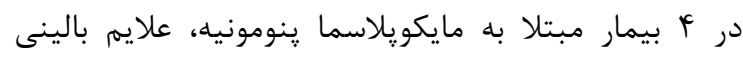

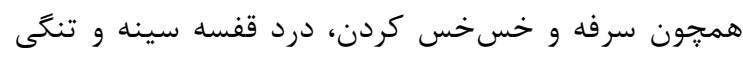

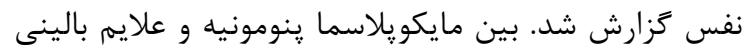

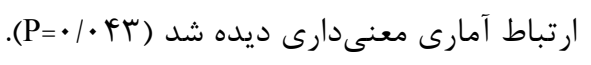


(Tr) (T) در مطالعه Apfalter همكارانش با استفاده از روش real time-PCR

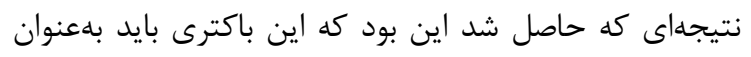

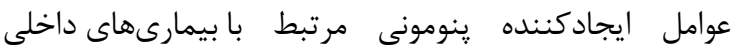

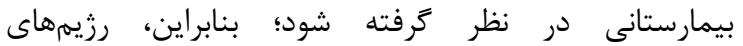

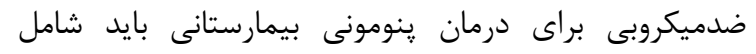

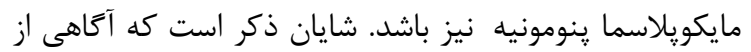

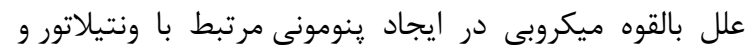
تائيد علت خاص آن در يك بيمار، براى درمان دران آنتىبيوتيكى إنى

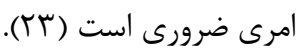
اهداف رنى متنوعى در روش PCR براى شناسايى مايكويلاسما

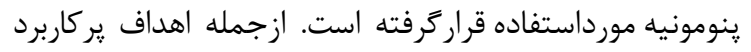

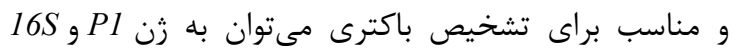

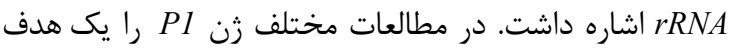

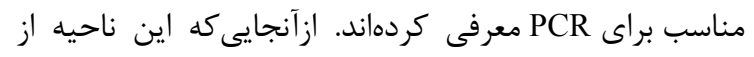

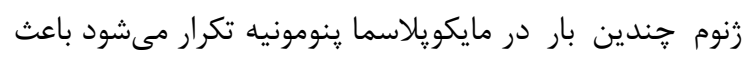

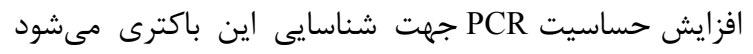

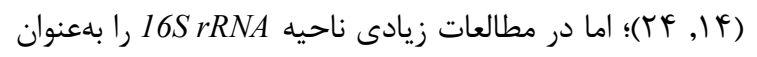
هدفى مناسب جهت شناسايى باكترى مايكويلاسما ينومونيه

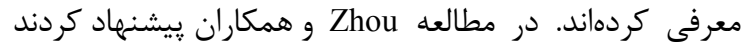

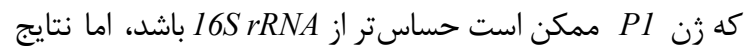
حاصل از اين مطالعه نشان داد به دمان دليل إن اينكه تعداد موارد

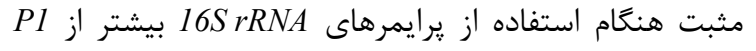

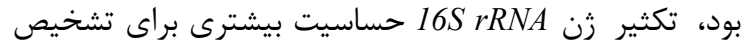

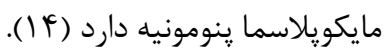

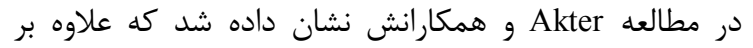

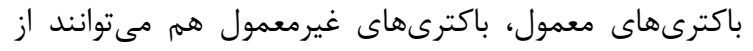

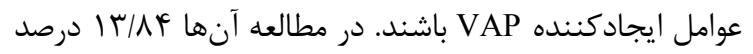
موارد VAP با عفونت باكترىهاى غير شايع مانند مايكويلاسما

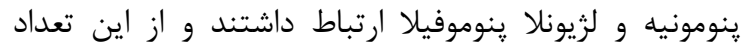

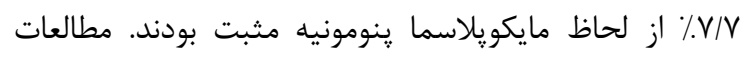

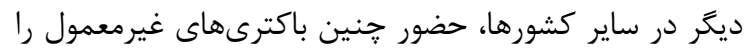

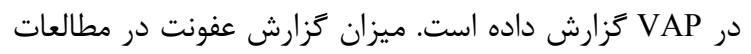

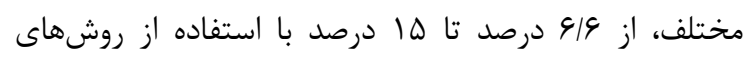

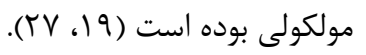

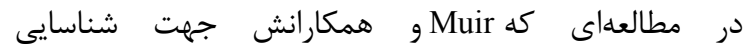

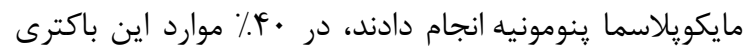

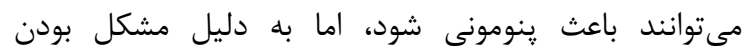

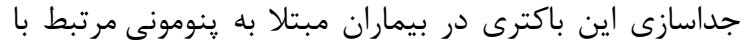

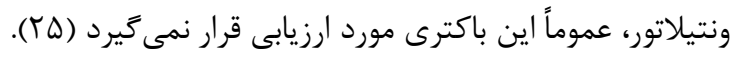

يكى از راههاى اصلى انتقال باكترىها به قسمت تحتانى

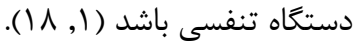

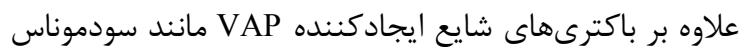
آئروزينوزا و استافيلوكوكوس اورئوس، جنديع إيناين مطالعه شيوع باكترىهاى غير شايع از قبيل لزيونلا ينوموفيلا، كلاميديا

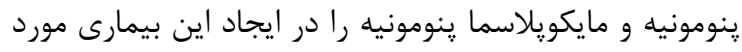
ارزيابى قرار دادهاند (9, 9 (1).

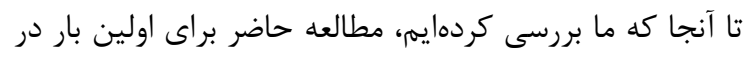

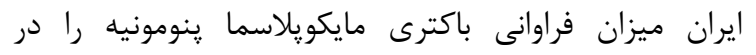
بيماران VAP با استفاده از روش nested-PCR و يرايمرهاي طراحىشده از ناحيه زن 16SrRNA مورد ارزيابى قرار داده

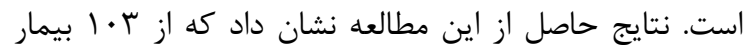

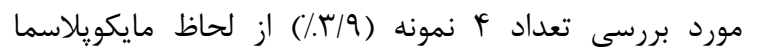
هنومونيه مثبت تشخيص داده شدند. ميزان شيوع اين باكترى

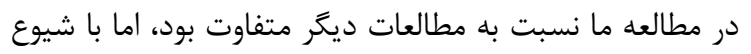

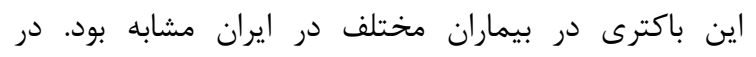

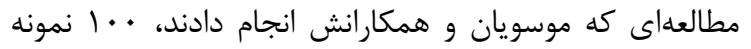

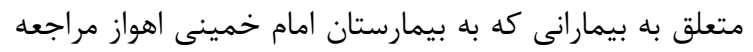

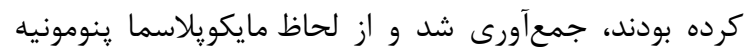
مورد بررسى قرار كرفت. در اين مطالعه، ميزان شيوع اين

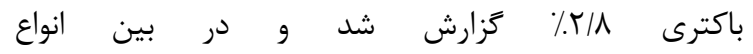

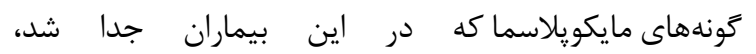
وجود مايكويلاسما ينومونيه بهعنوان يكى ياتوزن واقعى دستكاه

$$
\text { تنفسى مطرح شد (•) (Y). }
$$

در مطالعه Mokhless و همكارانش، نقش بالقوه باكترىهاى با بال

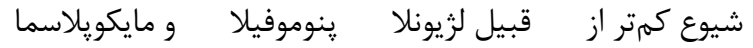
ينومونيه در ايجاد ينومونى مرتبط با ونتيلاتور مورد بررسى قرار

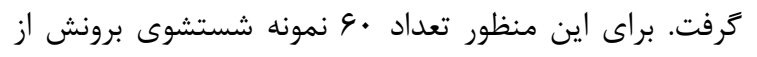

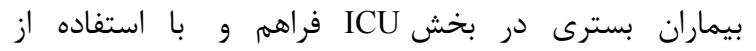
روش PCR به حضور اين باكترىها را مورد ارزيابى قراردادند.

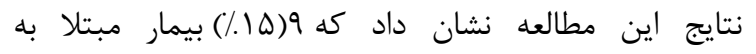

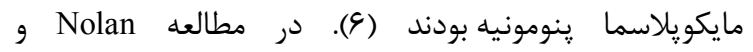

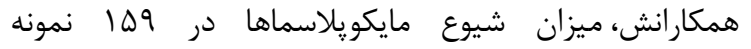

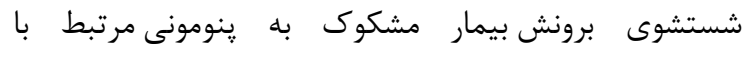

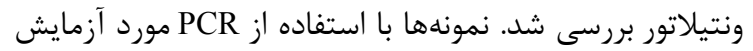

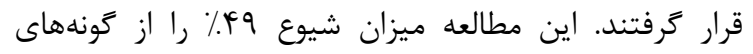

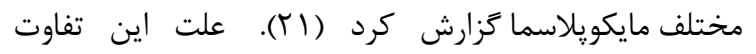

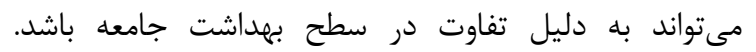

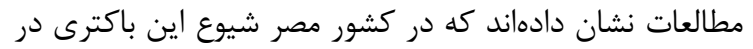
بيماران مختلف بسترى در بيمارستان در همين محدوده است دادهان 


$$
\begin{aligned}
& \text { به نظر مىرسد جهت مديريت عفونت VAP، علاوه بر درمان } \\
& \text { اختصاصى باكترىهاى شايع بايد باكترىهاى غير شايع نيز }
\end{aligned}
$$

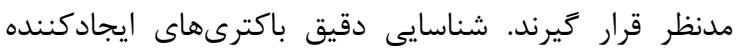

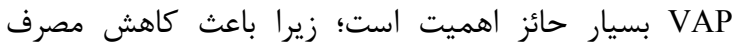

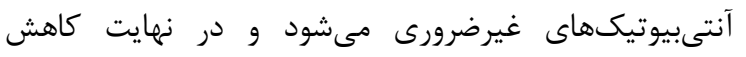

$$
\begin{aligned}
& \text { هزينههاى بهداشتى و درمانى مىشود (19 (1) ). } \\
& \text { نتايج حاصل از اين مطالعه براى اولين بار در ايران شيوع و }
\end{aligned}
$$

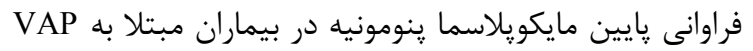

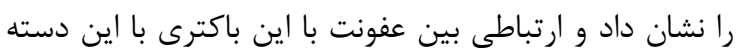

$$
\begin{aligned}
& \text { از بيماران ديده نشد. ساير يروهشهاى انجامشده در اين } \\
& \text { زمينه، نشان داد مايكويلاسما ينومونيه مىتواند بلهنوان ياتوزن } \\
& \text { واقعى دستخاه تنفسى، بهخصوص در بيماران ريوى، مطرح }
\end{aligned}
$$

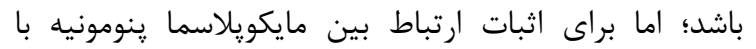

$$
\begin{aligned}
& \text { بيمارى VAP لازم است مطالعات جامعتر با تعداد نمونه } \\
& \text { بيشترى صورت يذيرد. }
\end{aligned}
$$$$
\text { تشكر و قدردانى }
$$$$
\text { از تمامى كاركنان بيمارستانهاى عرفان، عرفان نيايش و و }
$$

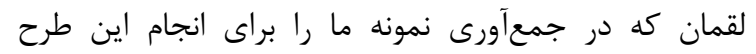$$
\text { تحقيقاتى يارى كردهاند، كمال تشكر را دارد. }
$$

در اين مطالعه از لحاظ آمارى بين مثبت بودن نمونهها و علائم بالينى ارتباط ديده شد. نمونههاى مثبت متعلق به بيمارانى بودند كه علائم بالينى همجون تب، تبن تراكئوبرونشيت، علائم مجارى تنفسى فوقانى، سردرد، بى حالى، گلودرد، درد عضلانى،

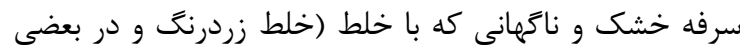
مواقع بار گههاى خون) همراه مىشد را داشتند كه با مطالعات

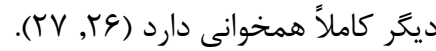
״نومونى حاصل از مايكويلاسما پِنومونيه يك بيمارى ملايهم،

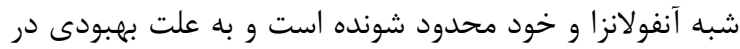

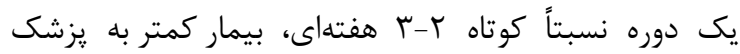

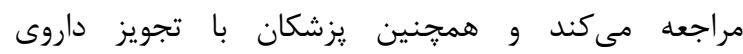

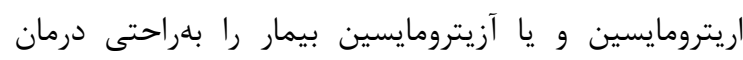

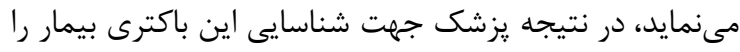

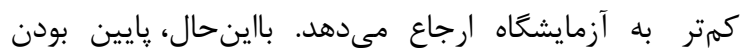

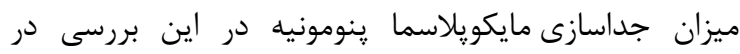
مقايسه با بعضى تحقيقات در ايران و يا در امريكا، ميىتواند به لهونيه دليل اختلاف در روش شناسايى باشد، زيرا كه با استفاده

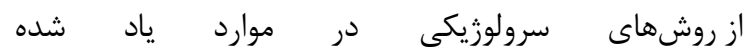

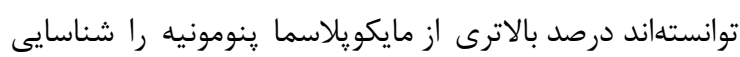

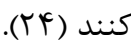

\section{REFERENCES}

1. Kalil AC, Metersky ML, Klompas M, Muscedere J, Sweeney DA, Palmer LB, et al. Management of adults with hospital-acquired and ventilator-associated pneumonia: 2016 clinical practice guidelines by the Infectious Diseases Society of America and the American Thoracic Society. Clin Infect Dis 2016;63: 61-111.

2. Othman AA, Abdelazim MS. Ventilator-associated pneumonia in adult intensive care unit prevalence and complications. The Egyptian Journal of Critical Care Medicine 2017;5:61-3.

3. Gadani H, Vyas A, Kar AK. A study of ventilator-associated pneumonia: Incidence, outcome, risk factors and measures to be taken for prevention. Indian J Anaesth 2010;54:535-40.

4. Kalanuria AA, Zai W, Mirski M. Ventilator-associated pneumonia in the ICU. Critical care 2014;18:208.

5. Muscedere JG, Day A, Heyland DK. Mortality, attributable mortality, and clinical events as end points for clinical trials of ventilator-associated pneumonia and hospital-acquired pneumonia. Clin Infect Dis 2010;51: 120-25.

6. Mokhless NA-S, El-Mofty MF, Hanafi NF, Muhammad A. Atypical bacteria in ventilator associated pneumonia; an Egyptian University Hospital experience. J Am Sci 2010;6:1074-79.

7. Saraya T. Mycoplasma pneumoniae infection: Basics. J Gen Fam Med 2017;18:118-25.

8. Meyer Sauteur PM, Unger WW, Nadal D, Berger C, Vink C, van Rossum A. Infection with and Carriage of Mycoplasma pneumoniae in Children. Front Microbiol 2016; 23: 329.

9. Atkinson TP, Balish MF, Waites KB. Epidemiology, clinical manifestations, pathogenesis and laboratory detection of Mycoplasma pneumoniae infections. FEMS Microbiol Rev 2008;32:956-73.

10. Saraya T. The history of Mycoplasma pneumoniae pneumonia. Front Microbiol 2016;7:364.

11. Principi N, Esposito S, Blasi F, Allegra L, Group MS. Role of Mycoplasma pneumoniae and Chlamydia pneumoniae in children with community-acquired lower respiratory tract infections. Clin Infect Dis 2001;32:1281-9.

12. Gardiner SJ, Gavranich JB, Chang AB. Antibiotics for community-acquired lower respiratory tract infections secondary to Mycoplasma pneumoniae in children. Cochrane Database Syst Rev 2015;1-CD004875. 
13. Nour M, Trabelsi A, Maatouk N, Hammami M. Amplification of P1 and 16S rRNA genes by nested PCR for detection of Mycoplasma pneumoniae in paediatric patients. Pathologie Biologie 2005;53:9-14.

14. Zhou Z, Li X, Chen X, Yao L, Pan C, Huang H, et al. Comparison of P1 and 16S rRNA genes for detection of Mycoplasma pneumoniae by nested PCR in adults in Zhejiang, China. J Infect Dev Ctries 2015;9:244-53.

15. Bucholtz GA, Salzman SA, Bersalona FB, Boyle TR, Ejercito VS, Penno L, et al. PCR analysis of nasal polyps, chronic sinusitis, and hypertrophied turbinates for DNA encoding bacterial 16S rRNA. Am J Rhinol 2002;16:169-73.

16. Thumerelle C, Deschildre A, Bouquillon C, Santos C, Sardet A, Scalbert M, et al. Role of viruses and atypical bacteria in exacerbations of asthma in hospitalized children: a prospective study in the Nord $\square$ Pas de Calais region (France). Pediatr Pulmonol 2003;35:75-82.

17. Han X, Li S, Lu S, Liu L, Li S, Zhang J. Amplification of $16 \mathrm{~S}$ rDNA by nested PCR for measurement of Mycoplasma pneumoniae DNA over time: clinical application. J Med Microbiol 2012;61:426-30.

18. Alp E, Voss A. Ventilator associated pneumonia and infection control. Ann Clin Microbiol Antimicrob 2006;5:7.

19. Akter S, Khatun R, Shamsuzzaman S. Molecular detection of atypical microorganisms in patients with ventilator associated pneumonia. Ibrahim Med Coll J 2015;9:22-5.

20. Moosavian S, Pordeli H. Survey of respiratory and urogenital infections due to Mycoplasma in the hospitalized patients in Ahwaz Imam Khomeini Hospital. Journal of Kerman University of Medical Sciences 2003;10:185-192. [In Persian]

21. Nolan T, Gadsby N, Hellyer T, Templeton K, McMullan R, McKenna J, et al. Low-pathogenicity Mycoplasma spp. alter human monocyte and macrophage function and are highly prevalent among patients with ventilator-acquired pneumonia. Thorax 2016;71:594-600.

22. El Seify MY, Fouda EM, Ibrahim HM, Fathy MM, Al Husseiny Ahmed A, Khater WS, et al. Microbial etiology of community-acquired pneumonia among infants and children admitted to the pediatric hospital, Ain Shams University. Eur J Microbiol Immunol 2016; 6:206-214 .

23. Apfalter P, Stoiser B, Barousch W, Nehr M, Kramer L, Burgmann H. Community-acquired bacteria frequently detected by means of quantitative polymerase chain reaction in nosocomial early-onset ventilator-associated pneumonia. Crit Care Med 2005;33:1492-8.

24. Yamazaki T, Kenri T. Epidemiology of Mycoplasma pneumoniae infections in Japan and therapeutic strategies for macrolide-resistant M. pneumoniae. Front Microbiol 2016;7:693.

25. Muir MT, Cohn SM, Louden C, Kannan TR, Baseman JB. Novel toxin assays implicate Mycoplasma pneumoniae in prolonged ventilator course and hypoxemia. Chest 2011;139:305-10.

26. Izumikawa K. Clinical features of severe or fatal Mycoplasma pneumoniae pneumonia. Front Microbiol 2016;7:800.

27. Kashyap S, Sarkar M. Mycoplasma pneumonia: Clinical features and management. Lung India 2010;27:75-85. 